\title{
Partial replacement of sodium chloride with potassium chloride or ammonium chloride in a prepared meal - cooked peas with pork burger
}

\author{
Mladen Raseta ${ }^{1}$, Ivana Brankovic Lazic ${ }^{1}$, Slobodan Lilic*1, Nenad Katanic ${ }^{2}$, Nenad Parunovic ${ }^{1}$, \\ Vladimir Koricanac ${ }^{1}$, Jelena Jovanovic ${ }^{1}$
}

A b s tra c t: The aim of this study was to examine the influence of reducing the sodium content in a prepared meal-cooked peas with pork burger - by partial replacement of sodium chloride with potassium chloride or ammonium chloride, with the target of achieving the same salty taste with less sodium content. In the control group of both cooked peas and pork burgers, only sodium chloride was added. In group 1, one third of sodium chloride was replaced with potassium chloride, while in group 2, one half of the sodium chloride was replaced with potassium chloride. In group 3, one third of the sodium chloride was replaced with ammonium chloride and in group 4, sodium chloride was reduced by one half, and one quarter of ammonium chloride was added compared to the control group. Saltiness was less acceptable in the cooked peas from the control group and from group 3 and can be connected with the too intense salty taste of both these pea groups and the appearance of a bitter taste in cooked peas from group 3. In the pork burgers, intensity of saltiness was higher in the control and group 3 burgers than in group $1(P \leq 0.05)$ or in group 2 and group 4 (P $\leq 0.01)$ products. The taste of cooked peas from group 3 was not acceptable due to their having the most intense saltiness. In the case of burgers, the taste was acceptable for products from all examined groups, and the only statistical difference was between the taste acceptability of control and group 3 burgers $(P \leq 0.01)$.

Keywords: cooked peas, pork burgers, sodium chloride reduction, potassium chloride, ammonium chloride.

\section{Introduction}

Prepared and ready-to-eat meals have become an important choice for modern people with respect to their fast lifestyles, particularly in developed countries. Nowadays, meat products and prepared meat meals are often the subject of scientific examination to reduce their sodium chloride content, with the aim of achieving lower sodium content and a better sodium:potassium ratio in the food. Daily dietary sodium intake mainly exceeds the level recommended by World Health Organization, and that can cause several debilitative health effects, primarily linked to essential hypertension and consequent cardiovascular disorders. It has been estimated that $62 \%$ of stroke and $49 \%$ of coronary heart disease is caused by high blood pressure (Brown et al., 2009).

Sodium chloride has an important role in meat products and in home-prepared meals, and it is the prototypical stimulus for salty taste (Dotsch et al.,
2009). Sodium chloride improves the sensory properties of food by increasing saltiness, decreasing bitterness and increasing sweetness and other congruent flavour effects (Keast and Breslin, 2003). Saltiness perception is a very complex system and can be explained by the unique sodium-specific transduction mechanism involving epithelial sodium channels (ENaCs) on the taste receptor cells (Chandrashekar et al., 2010). Identification of saltiness occurs when the concentration of sodium is high enough not only to activate the taste receptors, but also produce electrical impulses, which are carried via sensory neurons to the brain where they are decoded, after which the taste quality is identified (Liem et al., 2011).

Dietary sodium intake can be reduced in several ways such as a sodium restricted diet, sodium reduction by stealth, use of salt substitutes and other approaches (Liem et al., 2011). Use of other salts has the aim of partial replacement of sodium chloride and can be used to reduce the sodium content 
of meat products, but this is also linked with an appearance of bitter and metallic tastes in the products. The most common sodium chloride replacer is potassium chloride, followed by magnesium and calcium salts and ascorbates (Ruusunen and Puolanne, 2005). There are several studies on sodium reduction in cooked sausages, dry fermented sausages and dry meat. However, the meat industry is an important producer of ready-to-eat meals prepared or cooked in advance, with no further cooking or preparation required before being eaten.

There are not many literature data on the use of sodium chloride substitutes in prepared meat meals. Some authors examined the partial replacement of sodium chloride with potassium chloride in meat burgers (Lilic et al., 2015), as well as the use of potassium chloride and ammonium chloride as partial replacers of sodium chloride in the prepared meat meal, meatballs in tomato sauce (Lilic et al., 2017). Some others (Murray and Shackelford, 1991) found that ammonium chloride combined with autolysed yeast could be a suitable replacer of sodium chloride in some meat products. Commercial use of sodium chloride replacers is still restricted, but presently, potassium chloride and ammonium chloride are both recognized as safe.

The aim of this study was to examine the influence of reducing the sodium content in a prepared meal - cooked peas with pork burger - by partial replacement of sodium chloride with potassium chloride or ammonium chloride, with the target of achieving the same salty taste with a lower sodium content.

\section{Materials and Methods}

The trial consisted of five groups of samples, the compositions of which are presented in Tables 1 and 2. In the control group of both cooked peas and pork burgers, only sodium chloride was added. In group 1, one third of sodium chloride was replaced with potassium chloride, while in group 2, one half of the sodium chloride was replaced with potassium chloride. In group 3, one third of the sodium chloride was replaced with ammonium chloride and in group 4, sodium chloride was reduced by a half and replaced with the same amount of ammonium chloride.

\section{Meat preparation}

Minced onion was fried in sunflower oil and red pepper was added. After that, frozen green peas, salt, sucrose and water were added. The peas were cooked for one hour.

Burgers were prepared from minced pork leg meat (grind plate $3 \mathrm{~mm}$ ) purchased from a local market. Meat was well mixed with the ingredients in Table 2 to achieve optimal consistency to form into round shapes and roasted after that.

\section{Sensory evaluation}

Sensory evaluation was performed by ten trained panellists (SRPS ISO 8586, 2015) using numeric scales. Each sensory characteristic was evaluated for both ingredients of the complete meal, cooked peas and pork burgers. Colour acceptability, consistency, saltiness acceptability and taste acceptability were evaluated with a 1-5 point scale, where 1 was the least acceptable and 5 was the most acceptable. Intensity of saltiness was evaluated with a $1-5$ point scale, where 5 was the most expressed attribute and 1 was the least expressed attribute. Preparation and presentation of the samples to the assessors (number, coding and randomization) as well as the fitting out of the serving area (isolation of panellists, lighting conditions) were performed according to Baltic and Karabasil (2011). The final ranking was done according to the sum of all sensory evaluation results where the best scored meal was ranked highest and the worst ranked lowest.

Table 1. Composition of cooked peas, $\mathrm{g}$ or $\mathrm{ml}$.

\begin{tabular}{cccccccccc}
\hline Group & $\begin{array}{c}\text { Minced } \\
\text { onion, }\end{array}$ & $\begin{array}{c}\text { Sunflower } \\
\text { oil, } \mathbf{m l}\end{array}$ & $\begin{array}{c}\text { Red } \\
\text { pepper, } \mathbf{g}\end{array}$ & $\begin{array}{c}\text { Frozen } \\
\text { peas, }\end{array}$ & $\begin{array}{c}\text { Sodium } \\
\text { chloride, } \mathbf{g}\end{array}$ & $\begin{array}{c}\text { Sucrose, } \\
\text { g }\end{array}$ & $\begin{array}{c}\text { Water, } \\
\text { ml }\end{array}$ & $\begin{array}{c}\text { Potassium } \\
\text { chloride, },\end{array}$ & $\begin{array}{c}\text { Ammonium } \\
\text { chloride, }\end{array}$ \\
\hline Control & 70 & 20 & 5 & 450 & 20.50 & 30 & 450 & - & - \\
1 & 70 & 20 & 5 & 450 & 13.66 & 30 & 450 & 6.83 & - \\
2 & 70 & 20 & 5 & 450 & 10.25 & 30 & 450 & 10.25 & - \\
3 & 70 & 20 & 5 & 450 & 13.66 & 30 & 450 & - & 6.83 \\
4 & 70 & 20 & 5 & 450 & 10.25 & 30 & 450 & - & 5.13 \\
\hline
\end{tabular}


Table 2. Composition of burgers, g.

\begin{tabular}{ccccc}
\hline Group & Pork, $\mathbf{g}$ & Sodium chloride, $\mathbf{g}$ & Potassium chloride, $\mathbf{g}$ & Ammonium chloride, $\mathbf{g}$ \\
\hline Control & 500 & 10.00 & - & - \\
$\mathbf{1}$ & 500 & 6.70 & 3.30 & - \\
$\mathbf{2}$ & 500 & 5.00 & 5.00 & - \\
$\mathbf{3}$ & 500 & 6.70 & - & 3.30 \\
$\mathbf{4}$ & 500 & 5.00 & - & 2.50 \\
\hline
\end{tabular}

\section{Statistical evaluation}

The results obtained were statistically evaluated using Microsoft Excel 2010 and are presented as mean \pm SD. Statistical differences between means of the examined parameters were determined on the level 0.05 and 0.01 by Student's t-test.

\section{Results and discussion}

The results of sensory evaluation of colour and consistency of cooked peas and pork burgers are presented in Table 3.

Colour acceptability was evaluated similarly for cooked peas (range $4.30 \pm 0.68$ to $4.55 \pm 0.42$ ) and for pork burgers (range $4.00 \pm 0.89$ to $4.40 \pm 0.62$ ). Also, evaluations of consistency were similar, without statistical differences between means $(\mathrm{P} \geq 0.05)$. For cooked peas, consistency was in the range $4.15 \pm 0.71$ to $4.45 \pm 0.65$ and for burgers, it was in the range $4.20 \pm 0.71$ to $4.35 \pm 0.59$. Reducing the sodium chloride and adding other salts did not affect these two sensory characteristics. The absence of any negative influence on product colour by the sodium chloride replacers we used was explained previously for meat burgers with added potassium chloride (Lilic et al., 2015) as well as for dry pork meat in which sodium chloride was partially replaced with potassium chloride and ammonium chloride (Lilic et al., 2016). Also, the use of potassium chloride and ammonium chloride as partial replacers of sodium chloride did not affect the colour of meatballs in tomato sauce (Lilic et al., 2017).

Sensory evaluation of saltiness acceptability, taste acceptability and saltiness intensity is presented in Table 4.

Saltiness acceptability was similarly evaluated in the cooked peas from groups 1, 2 and 4 $(4.00 \pm 0.97,3.65 \pm 1.10$ and $4.05 \pm 0.79$, respectively) without statistical differences $(\mathrm{P} \geq 0.05)$. Saltiness of control cooked peas scored lower, i.e., less fa-

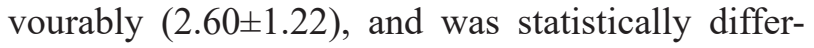
ent from all other groups $(\mathrm{P} \leq 0.01)$, including from the low-scoring group 3 peas $(1.45 \pm 0.47)$. The

Table 3. Sensory evaluation (mean $\pm \mathrm{SD} ; \mathrm{n}=10$ ) of colour acceptability and consistency of cooked peas and burgers.

\begin{tabular}{ccccc}
\hline \multirow{2}{*}{ Group } & \multicolumn{2}{c}{ Cooked peas } & \multicolumn{2}{c}{ Burgers } \\
\cline { 2 - 5 } & Colour acceptability & Consistency & Colour acceptability & Consistency \\
\hline Control & $4.55 \pm 0.42$ & $4.25 \pm 0.60$ & $4.40 \pm 0.62$ & $4.35 \pm 0.67$ \\
$\mathbf{1}$ & $4.55 \pm 0.42$ & $4.30 \pm 0.60$ & $4.35 \pm 0.78$ & $4.35 \pm 0.59$ \\
$\mathbf{2}$ & $4.40 \pm 0.62$ & $4.25 \pm 0.60$ & $4.15 \pm 0.78$ & $4.20 \pm 0.71$ \\
$\mathbf{3}$ & $4.30 \pm 0.68$ & $4.15 \pm 0.71$ & $4.00 \pm 0.89$ & $4.25 \pm 0.0 .72$ \\
$\mathbf{4}$ & $4.50 \pm 0.50$ & $4.45 \pm 0.65$ & $4.30 \pm 0.78$ & $4.35 \pm 0.63$ \\
\hline
\end{tabular}


Table 4. Sensory evaluation (mean $\pm \mathrm{SD} ; \mathrm{n}=10$ ) of saltiness acceptability, saltiness intensity and taste acceptability of cooked peas and burgers.

\begin{tabular}{ccccccc}
\hline \multirow{2}{*}{ Group } & \multicolumn{3}{c}{ Cooked peas } & \multicolumn{3}{c}{ Burgers } \\
\cline { 2 - 7 } & $\begin{array}{c}\text { Saltiness } \\
\text { acceptability }\end{array}$ & $\begin{array}{c}\text { Saltiness } \\
\text { intensity }\end{array}$ & $\begin{array}{c}\text { Taste } \\
\text { acceptability }\end{array}$ & $\begin{array}{c}\text { Saltiness } \\
\text { acceptability }\end{array}$ & $\begin{array}{c}\text { Saltiness } \\
\text { intensity }\end{array}$ & $\begin{array}{c}\text { Taste } \\
\text { acceptability }\end{array}$ \\
\hline Control & $2.60 \pm 1.22^{\mathrm{a}, \mathrm{x}}$ & $4.30 \pm 0.64^{\mathrm{a}, \mathrm{x}}$ & $3.10 \pm 1.22^{\mathrm{x}}$ & $3.85 \pm 1.03$ & $3.95 \pm 1.06^{\mathrm{a}, \mathrm{x}}$ & $4.25 \pm 0.84^{\mathrm{x}}$ \\
$\mathbf{1}$ & $4.00 \pm 0.97^{\mathrm{b}, \mathrm{y}}$ & $3.00 \pm 0.97^{\mathrm{b}}$ & $3.95 \pm 0.88^{\mathrm{x}}$ & $3.85 \pm 0.90$ & $3.30 \pm 0.78^{\mathrm{a}}$ & $4.00 \pm 0.97$ \\
$\mathbf{2}$ & $3.65 \pm 1.10^{\mathrm{y}}$ & $2.65 \pm 0.84^{\mathrm{y}, \mathrm{c}}$ & $3.75 \pm 0.87^{\mathrm{x}}$ & $3.55 \pm 1.01$ & $2.80 \pm 1.47^{\mathrm{b}}$ & $3.70 \pm 0.87$ \\
$\mathbf{3}$ & $1.45 \pm 0.47^{\mathrm{c}, \mathrm{y}, \mathrm{z}}$ & $4.15 \pm 1.23^{\mathrm{a}, \mathrm{x}}$ & $1.55 \pm 0.47^{\mathrm{y}}$ & $3.10 \pm 0.97$ & $3.80 \pm 1.47^{\mathrm{x}}$ & $3.30 \pm 1.12^{\mathrm{y}}$ \\
$\mathbf{4}$ & $4.05 \pm 0.79^{\mathrm{y}}$ & $1.60 \pm 1.20^{\mathrm{z}, \mathrm{c}}$ & $4.00 \pm 0.87^{\mathrm{x}}$ & $3.80 \pm 0.90$ & $2.10 \pm 1.22^{\mathrm{b}, \mathrm{y}}$ & $3.65 \pm 1.03$ \\
\hline
\end{tabular}

Legend: ${ }^{(a, b, c)}$ Values (mean $\left.\pm S D\right)$ with different superscript letters are significantly different $(\mathrm{P} \leq 0.05)$

$(\mathrm{x}, \mathrm{y}, \mathrm{z,q}, \mathrm{V})$ Values ( mean $\pm \mathrm{SD}$ ) with different superscript letters are significantly different $(\mathrm{P} \leq 0.01)$

less acceptable saltiness of groups 2 and 3 cooked peas was connected with the too intense salty taste and with the appearance of a bitter taste in group 3 cooked peas. The saltiness of all roasted pork burgers was acceptable and there were no statistical differences between means $(\mathrm{P} \geq 0.05)$.

Intensity of saltiness was the highest in cooked peas from the control group and group 3, and these values were significantly different from groups 2 and 4 cooked peas $(\mathrm{P} \leq 0.01)$ and from group 1 peas $(\mathrm{P} \leq 0.05)$. Saltiness was the most highly expressed in control cooked peas $(4.30 \pm 0.64)$, due to this group containing the largest amount of added sodium chloride, and in group 3 cooked peas (4.15 \pm 1.23$)$. The saltiness intensity of this latter group, even with its low sodium chloride content, was likely because the ammonium chloride added in a relatively large amount probably acted as an enhancer of salty taste. In the pork burgers, intensity of saltiness was significantly higher in the control and group 3 products than in burgers from group $1(\mathrm{P} \leq 0.05)$ and in those from groups 2 and 4 $(\mathrm{P} \leq 0.01)$. This order of saltiness intensity was according to amount of added sodium chloride in the burgers. Similarly to cooked peas from group 3, saltiness intensity was high in burgers from group $3(3.80 \pm 1.47)$.

The taste of cooked peas from all groups was acceptable, except that of group 3 peas $(1.55 \pm 0.47)$, which was due to the most intense, unacceptable saltiness in these peas and which was statistically different from other pea groups. Evaluations of taste acceptability of other groups of cooked peas were similar, with no statistical differences $(P \geq 0.05)$ between them. In the case of burgers, the taste of burgers from all groups was acceptable, and the only statistically significant difference was the more acceptable taste of control burgers than group 3 burgers $(\mathrm{P} \leq 0.01)$.

Complete meals (cooked peas with pork burger) were ranked in the following order according to the sensory evaluations, from most acceptable to least acceptable: group $2>$ control $>$ group $1>$ group $4>$ group 3 .

The most common substitute of sodium chloride is potassium chloride, but other chloride salts such as calcium chloride, magnesium chloride, lithium chloride and ammonium chloride are also potential sodium replacers. As with potassium chloride, potential use of these salts is restricted by their unacceptable flavours. There is very little literature data on the use of sodium chloride replacers in prepared meat dishes. Commercial use of sodium chloride substitutes is further restricted to those substances having FDA approval (Murray and Shackelford, 1991). For example, lithium chloride is not allowed because of its pharmokinetic impact. Presently, however, potassium chloride and ammonium chloride are both recognized as safe. Ammonium chloride does not belong to the list of recognised food additives, but has a somewhat special status among the nutritionally acceptable mineral salts (Cepanec et al., 2017). Due to the close similarity of ammonium cation with the alkali metal cations sodium and potassium, ammonium chloride exhibits roughly similar properties to those of sodium chloride and potassium chloride. According to Murray and Shackelford (1991), ammonium chloride gives a stronger, less acceptable flavour to food when used alone, but in combination with other chloride salts, contributes to a saltier flavour, particularly when combined with potassium chloride. These authors examined a mixture of ammonium chloride and autolysed yeast as a sodium chloride replacer and found this mixture 
strongly enhanced salt flavour intensity, and, when incorporated into processed meats, aided in solubilisation of proteins and texturisation.

In conclusion, both potassium chloride and ammonium chloride are suitable substituents for sodium chloride in ready-to-eat meat meals, whether added individually or added in different proportions.

\section{Conclusion}

Reduction of sodium chloride content and partial replacement with potassium chloride and ammonium chloride did not affect colour acceptability or consistency of either cooked peas or pork burgers.

Saltiness acceptability was similarly evaluated in the cooked peas from groups 1,2 and 4. The less acceptable saltiness of control and group 3 cooked peas was connected with the too intense salty flavour and bitterness in peas with ammonium chloride. The saltiness of all the roast pork burgers was acceptable. Saltiness intensity was the highest in the control burgers, as these contained the largest amount of added sodium chloride, and in group 3 burgers, probably because ammonium chloride enhanced the salty taste of this product.

The taste of cooked peas from all groups was acceptable, except for group 3 peas, due to them having the most intense, unacceptable saltiness. In the case of burgers, the taste of burgers from all groups was acceptable. The only statistically significant difference in taste acceptability was between the more acceptable taste of control burgers than of the group 3 burgers.

The complete meat meals were ranked according to sensory evaluations, with group 2 meals ranked the highest (ahead of the control meals) and group 3 meals ranked the lowest.

According to the obtained results, shown by sensory characteristics and according to complete meal ranking, it can be concluded that either potassium chloride or ammonium chloride could be suitable partial substituents of sodium chloride in this type of prepared meat meal; potassium chloride would seem particularly suitable.

\title{
Parcijalna supstitucija natrijum hlorida kalijum hloridom i amonijum hloridom u pripremljenom jelu sa mesom - grašak sa faširanom šniclom
}

\author{
Mladen Rašeta, Ivana Branković Lazić, Slobodan Lilić, Nenad Katanić, Nenad Parunović, \\ Vladimir Koričanac, Jelena Jovanović
}

Apstrakt: Cilj rada bio je da se ispita uticaj smanjenja sadržaja natrijuma u pripremljenom jelu - grašak sa faširanom šniclom, delimičnom supstitucijom natrijum hlorida kalijum hloridom i amonijum hloridom u svrhu postizanja slične slanosti sa manjim sadržajem natrijuma. U kontrolnoj grupi uzoraka dodat je samo natrijum hlorid. U grupi 1, trećina natrijum hlorida zamenjena je kalijum hloridom, dok je u grupi 2, polovina natrijum hlorida zamenjena kalijum hloridom. U grupi 3, trećina natrijum hlorida zamenjena je amonijum hloridom, $i$, u grupi 4, natrijum hlorid je smanjen za polovinu, a četvrtina amonijum hlorida je dodata, $u$ odnosu na količinu soli u kontrolnoj grupi. Slanost je bila manje prihvatljiva u uzorcima kuvanog graška iz kontrolne i treće grupe zbog previše slanog ukusa i pojave gorkog ukusa u grašku iz treće grupe. U faširanim šniclama, intenzitet slanosti bio je viši u uzorcima kontrolne i treće grupe od one u uzorcima iz prve grupe $(P \leq 0.05)$ i iz druge i četvrte grupe $(P \leq 0.01)$. Ukus kuvanog graška iz treće grupe nije bio prihvatljiv usled najviše izražene slanosti. Ukus faširanih šnicli iz svih ispitivanih grupa bio je prihvatljiv, a jedina statistička razlika utvrđena je između uzoraka kontrolne i treće grupe $(P \leq 0.01)$.

Ključne reči: kuvani grašak, faširane šnicle, redukcija natrijum hlorida, kalijum hlorid, amonijum hlorid.

Disclosure statement: No potential conflict of interest was reported by authors.

Acknowledgements: This study was funded by grants TR 31083 and III 46009 from the Ministry of Education, Science and Technological Development, Republic of Serbia. 


\section{References}

Baltic Z. M. \& Karabasil N. (2011). Kontrola namirnica animalnog porekla. Fakultet veterinarske medicine.

Brown I., Tzoulaki I., Candeias V. \& Elliott P. (2009). Salt intakes around the world: Implications for public health. International Journal of Epidemiology, 38, 780-791.

Cepanec K., Vugrinec S., Cvetkovic T. \& Ranilovic J. (2017). Potassium chloride-based salt substitutes: A critical review with a focus on the patent literature. Comprehensive Reviews in Food Science and Food Safety, 16, 881-894.

Chandrashekar J., Kuhn C., Oka Y., Yarmolinsky D. A., Hummler E., Ryba N. J. U. \& Zuker C. S. (2010). $\mathrm{Na}$ ture, 464, 297-301.

Dotsch M., Busch J., Batenburg M., Liem G., Tareilus E., Mueller R. \& Meijer G. (2009). Strategies to reduce sodium consumption: A food industry perspective. Critical Reviews in Food Science and Nutrition 49, 841-851.

Keast R. S. J. \& Breslin P. A. S. (2003). An overview of binary taste-taste interactions. Food Quality and Preference $14,111-124$.

Liem D. G., Fatemeh M. \& Keast R. S. J. (2011). Reducing sodium in foods: The effect on flavor. Nutrients 3, 694-711.

Lilic S., Brankovic I., Koricanac V., Vranic D., Spalevic Lj., Pavlovic M., Lakicevic B. (2015). Reducing sodium chloride content in meat burgers by adding potassium chloride and onion. International $58^{\text {th }}$ Meat Industry Conference "Meat Safety and Quality: Where it goes?" Procedia Food Science, 5, 164-167.

Lilic S, Babic J., Borovic B., Spalevic Lj., Maslic-Strizak D., Pavlovic M., Milijasevic M. (2016). Effect of sodium chloride reduction in dry pork on sensory quality parameters and instrumentally measured colour. Biotechnology in Animal Husbandry, 32, 4, 383-391.

Lilic S., Karan D., Jovanovic J., Babic J., Borovic B., Stefanovic S., Raseta M. 2017. Possibility of partial replacement of sodium chloride with potassium chloride and ammonium chloride in production of meatballs in tomato sauce. Meat Technology, 58, 1, 47-51.

Murray D. G. \& Shackelford J. R. (1991). Sodium chloride substitute containing autolyzed yeast and ammonium chloride. Patent number 5,064,663. United States Patent.

Ruusunen M. \& Puolanne E. (2005). Reducing sodium intake from meat products. Meat Science, 70, 3, 531-541.

SRPS EN ISO 8586. (2015). Senzorske analize - Opsta uputstva za odabir, obuku i pracenje odabranih ocenjivaca i strucnjaka za senzorska ocenjivanja.

Van Der Klaauw N. J. \& Smith D. V. (1995). Taste quality profiles for fifteen organic and inorganic salts. Physiology \& Behaviour 58, 295-306. 